\title{
A chromosome map of the European stone fruit yellows phytoplasma
}

\author{
Carmine Marcone† and Erich Seemüller \\ Author for correspondence: Carmine Marcone. Tel: +390971 205519. Fax: + 390971205503. \\ e-mail:ma513agr@unibas.it
}

Biologische Bundesanstalt für Land- und

Forstwirtschaft, Institut für Pflanzenschutz im Obstbau, D-69221 Dossenheim, Germany

\begin{abstract}
A physical map of the European stone fruit yellows phytoplasma strain GSFY1 chromosome was constructed using PFGE-purified genomic DNA from diseased tobacco and tomato plants. The map was generated with single and double digestions of the chromosome with Smal, BssHII, Apal, BamHI and Xhol restriction endonucleases and the fragments were resolved by PFGE. Reciprocal double digestions were used to locate 26 restriction sites on the chromosome. Southern blot analysis was also used to assist in the arrangement of the contiguous restriction fragments obtained. From the restriction fragments generated by double digestion, the circular chromosome was calculated to be approximately $635 \mathrm{~kb}$. Loci of two rRNA operons, the operon containing the tuf gene, genes encoding an immunodominant membrane protein and a putative nitroreductase, and randomly cloned DNA fragments IH184 and AT67 were placed on the map. Digestion of chromosomal DNA of strain GSFY1 with MluI gave a complex restriction pattern, suggesting that this isolate consists of a population with heterogeneity with respect to Mlul restriction sites. The GSFY1 physical map was different from that of the closely related apple proliferation phytoplasma but the genetic arrangement was similar.
\end{abstract}

Keywords: prokaryotes, genome size, yellows diseases, pulsed-field gel electrophoresis, ribosomal genes

\section{INTRODUCTION}

The European stone fruit yellows (ESFY) phytoplasma is an important prokaryotic pathogen that infects most or all kinds of stone fruits in Europe and is known to cause apricot chlorotic leaf roll, leptonecrosis and decline of Japanese plum (Prunus salicina), as well as yellows and decline diseases of peach, almond, European plum (Prunus domestica) and flowering cherry (Prunus serrulata) (Lorenz et al., 1994; Marcone et al., 1996). This organism is closely related to other important fruit tree pathogens, the apple proliferation (AP), pear decline and peach yellows leaf roll agents, and forms with them a distinct phylogenetic cluster, the AP group (Seemüller et al., 1998). In contrast to the progress made in differentiation, classification and detection of phytoplasmas, very little is known about how these pathogens induce disease. Understanding pathogenicity on the

\footnotetext{
† Present address: Università degli Studi della Basilicata, Dipartimento di Biologia, Difesa e Biotecnologie Agro-Forestali, Campus Macchia Romana, I-85100 Potenza, Italy.

Abbreviations: AP, apple proliferation; ESFY, European stone fruit yellows; SPLL, sweet potato little leaf; WX, western X-disease.
}

molecular level requires construction of a physical map followed by information on the genomic organization of the pathogen. With culturable organisms, a physical map can easily be generated using PFGE of large fragments which can be assembled using hybridization and fingerprinting methods (Pyle \& Finch, 1988; Colman et al., 1990; Ladefoged \& Christiansen, 1992). Unculturable phytoplasmas can be studied using these methods only when the colonization density of the pathogens in the host is high. Thus, only three phytoplasmas, the western X-disease (WX), AP and sweet potato little leaf (SPLL) agents, have been mapped so far, using PFGE resolution of large fragments (Firrao et al., 1996; Lauer \& Seemüller, 2000; Padovan et al., 2000). As a first step towards a detailed genetic characterization of the ESFY phytoplasma, we constructed a physical map of its chromosome, employing an approach similar to that used by Firrao et al. (1996), who generated the first physical map of a phytoplasma chromosome, that of the WX agent.

\section{METHODS}

Phytoplasma sources and transmission experiments. Strain GSFY1 of the ESFY phytoplasma, which was previously 
Table 1. Number and mean size $(\mathrm{kb})$ of fragments obtained by single and double digestions of the chromosome of strain GSFY1 of the ESFY phytoplasma

The mean of the sums of the restriction fragments generated from double digestions was $635 \mathrm{~kb}$.

\begin{tabular}{|c|c|c|c|c|c|c|c|c|c|c|c|c|c|c|c|}
\hline Fragment & SmaI & BssHII & ApaI & BamHI & XhoI & $\begin{array}{l}\text { SmaI/ } \\
\text { BssHII }\end{array}$ & $\begin{array}{c}\text { SmaI/ } \\
\text { ApaI }\end{array}$ & $\begin{array}{c}\text { SmaI/ } \\
\text { BamHI }\end{array}$ & $\begin{array}{c}\text { SmaI/ } \\
\text { XhoI }\end{array}$ & $\begin{array}{c}\text { BssHII/ } \\
\text { ApaI }\end{array}$ & $\begin{array}{l}\text { BssHII/ } \\
\text { BamHI }\end{array}$ & $\begin{array}{c}\text { BssHII/ } \\
\text { XhoI }\end{array}$ & $\begin{array}{c}\text { ApaI/ } \\
\text { BamHI }\end{array}$ & $\begin{array}{c}\text { ApaI/ } \\
\text { XhoI }\end{array}$ & $\begin{array}{c}\text { BamHI/ } \\
\text { XhoI }\end{array}$ \\
\hline A & 350 & 450 & 552 & 237 & 232 & 235 & 345 & 170 & 232 & 438 & 237 & 125 & 237 & 232 & 108 \\
\hline B & 284 & 65 & 65 & 121 & 153 & 220 & 205 & 121 & 153 & 65 & 113 & 104 & 121 & 95 & 100 \\
\hline C & & 50 & 15 & 113 & 80 & 65 & 65 & 113 & 80 & 50 & 65 & 80 & 113 & 80 & 80 \\
\hline D & & 50 & & 75 & 80 & 50 & 15 & 75 & 80 & 50 & 64 & 80 & 65 & 80 & 65 \\
\hline E & & 15 & & 64 & 25 & 50 & $2 *$ & 64 & 25 & 15 & 50 & 65 & 64 & 40 & 64 \\
\hline $\mathrm{F}$ & & & & 23 & 25 & 15 & & 64 & 25 & 15 & 50 & 35 & 23 & 25 & 56 \\
\hline G & & & & & 12 & $1^{*}$ & & 23 & 12 & $3 *$ & 23 & 35 & 10 & 25 & 52 \\
\hline $\mathrm{H}$ & & & & & 12 & & & $2 *$ & 12 & $2^{*}$ & 15 & 25 & $5 *$ & 15 & 25 \\
\hline I & & & & & 9 & & & & 9 & & 10 & 25 & $4^{*}$ & 12 & 22 \\
\hline $\mathrm{J}$ & & & & & 9 & & & & 9 & & $4 *$ & 15 & & 12 & 15 \\
\hline K & & & & & & & & & $1^{*}$ & & $1^{*}$ & 12 & & 9 & 12 \\
\hline $\mathrm{L}$ & & & & & & & & & $1^{*}$ & & & 12 & & 9 & 12 \\
\hline M & & & & & & & & & & & & 9 & & $1^{*}$ & 9 \\
\hline $\mathrm{N}$ & & & & & & & & & & & & 9 & & & 9 \\
\hline $\mathrm{O}$ & & & & & & & & & & & & $2 *$ & & & $4 *$ \\
\hline $\mathrm{P}$ & & & & & & & & & & & & & & & $3 *$ \\
\hline Total size & 634 & 630 & 632 & 633 & 637 & 636 & 632 & 632 & 639 & 638 & 632 & 633 & 642 & 635 & 636 \\
\hline
\end{tabular}

*Fragments predicted by restriction and alignment of larger fragments but not identified in PFGE gels.

transmitted from a diseased apricot tree to Catharanthus roseus (periwinkle) via dodder bridges (Cuscuta reflexa) (Marcone et al., 1999a), was used for mapping. In the course of this work, this strain was transmitted via dodder bridges to Nicotiana tabacum (tobacco) and from there by grafting to several Nicotiana species and other solanaceous plants, including tomato. The periwinkle-maintained strains ESFY1 (Loi et al., 1995) and GSFY2 (Marcone et al., 1999a) of the ESFY phytoplasma were also included in this study.

Chromosome isolation and restriction endonuclease digestion. Phytoplasma chromosomes were extracted from leaf midribs, cortical stem tissue or stem phloem preparations. Phloem was prepared as reported by Lauer \& Seemüller (2000), while sample preparation for PFGE and PFGE analysis was carried out as described by Neimark \& Kirkpatrick (1993), except that the lysis solution was changed several times, SeaPlaque agarose (FMC BioProducts) was used, and the blocks were not gamma-irradiated. PFGE was carried out in a CHEF DRIII apparatus (Bio-Rad Laboratories). Entire linearized ESFY phytoplasma chromosomes were isolated by PFGE, excised from the gel, washed twice for at least $30 \mathrm{~min}$ per wash with TE $(10 \mathrm{mM}$ Tris/HCl, $1 \mathrm{mM}$ EDTA, pH 8.0) on ice and once with the appropriate restriction buffer and then digested with rare cutting enzymes as reported by Lauer \& Seemüller (2000). Double digestions were carried out sequentially in the same preparation. After the first digestion, each preparation was first washed twice with TE and then with the appropriate restriction buffer, and then digested with a second restriction endonuclease. In addition, most major restriction fragments were excised from the gel and digested with the second enzyme individually. A concatameric lambda DNA ladder, Saccharomyces cerevisiae chromosomes (BioRad Laboratories) and a Low Range PFG Marker (New England BioLabs) were used as size markers.
Southern blot hybridization. Southern transfers were carried out as described by Neimark \& Kirkpatrick (1993). The following probes were used for hybridization: (a) linearized chromosomal DNA of strain GSFY1 recovered from the pulsed-field gel; (b) a PCR-amplified 1800 bp rDNA fragment of the ESFY phytoplasma comprising the entire $16 \mathrm{~S}$ rRNA gene and 16S/23S rDNA spacer region (Schneider et al., 1995); (c) a cloned fragment containing a gene encoding an immunodominant membrane protein (Berg et al., 1999); (d) a cloned fragment containing a gene encoding the elongation factor $\mathrm{Tu}$ (tuf) (Berg \& Seemüller, 1999); (e) randomly cloned fragment IH184 (Bonnet et al., 1990); (f) randomly cloned fragment AT67 (Schneider \& Seemüller, 1994); and (g) cloned fragment IH196 containing a putative nitroreductase gene (Jarausch et al., 1994). For probe preparation from entire GSFY1 chromosomes, DNA was recovered from the pulsed-field gel by agarase (Roche Diagnostics) digestion. PCR products as well as cloned fragments were eluted from conventional agarose gels using the QIAquick gel extraction kit (Qiagen). Probes were labelled with $\left[\alpha^{32} \mathrm{P}\right] \mathrm{dATP}$ using the Prime-It II kit (Stratagene). Hybridization was carried out according to the protocol of Hoheisel et al. (1991).

\section{RESULTS}

\section{Effect of plant sources on chromosome isolation}

Chromosomal DNA of strains ESFY1, GSFY1 and GSFY2 of the ESFY phytoplasma was initially extracted from midribs, cortical tissue and phloem preparations of periwinkle plants showing different stages of disease. However, only faint chromosomal DNA bands, insufficient for restriction analysis, were resolved by PFGE (data not shown). Higher concentrations of 

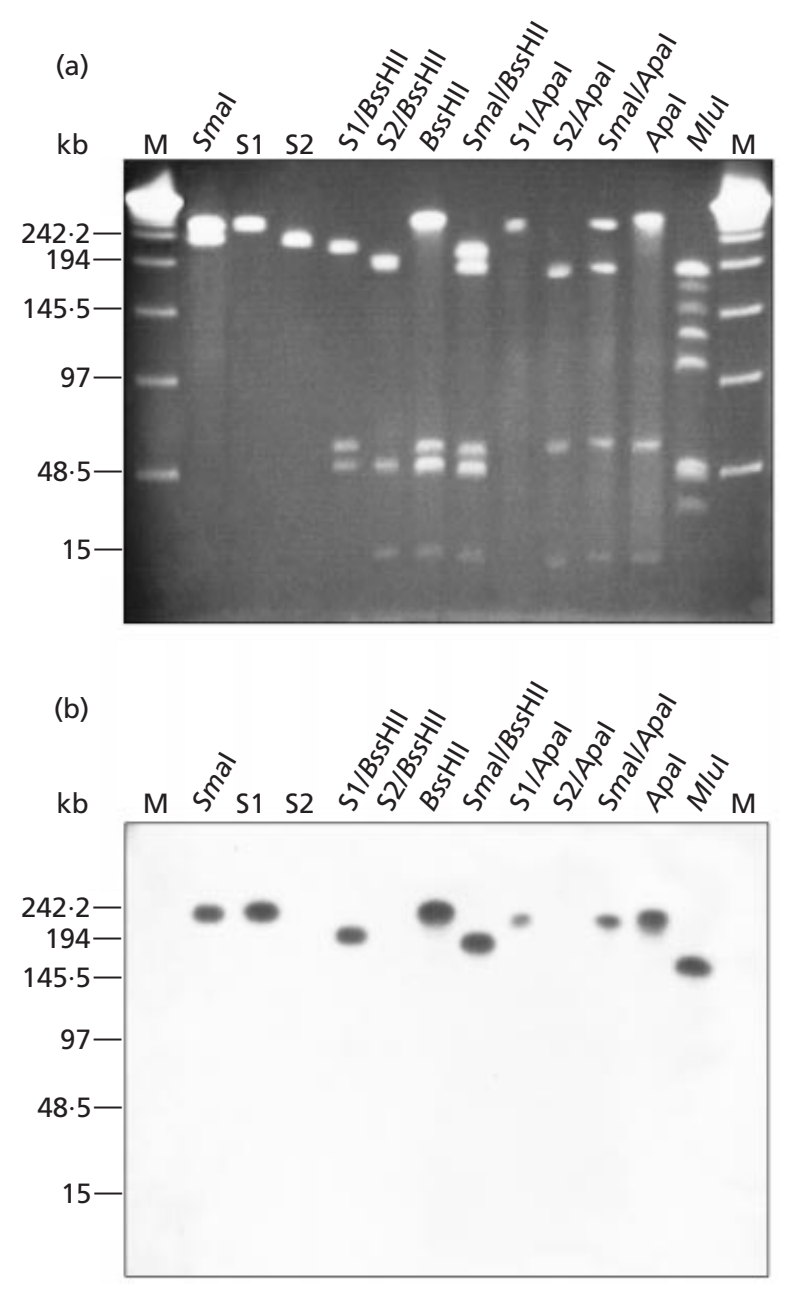

Fig. 1. PFGE of chromosomal DNA of the ESFY phytoplasma. (a) Ethidium-bromide-stained gel of single and double digests with various rare-cutting enzymes. S1 and S2, Smal restriction fragments which were previously separated under appropriate PFGE conditions $\left(1-21 \mathrm{~s}, 6 \mathrm{~V} \mathrm{~cm}^{-1}, 19 \mathrm{~h}\right)$ and excised from the gel in order to be used either undigested or digested separately with the second enzyme. $M$, concatameric lambda DNA ladder. PFGE parameters were $0.7-12.5 \mathrm{~s}, 6 \mathrm{~V} \mathrm{~cm}^{-1}, 18.8 \mathrm{~h}$. (b) Southern blot hybridization of DNA fragments obtained by single and double digestion with cloned DNA fragment probe AT67.

chromosomal DNA of the closely related AP phytoplasma were obtained from phloem preparations of $N$. tabacum cv. Samsun (Lauer \& Seemüller, 2000) so strain GSFY1 was transmitted to this plant via dodder bridges. However, this plant, too, was found to be an unsuitable host for this work, as were several other Nicotiana genotypes, including N. tabacum cv. White Burley, Nicotiana occidentalis, Nicotiana rustica, Nicotiana edwardsonii, Nicotiana debneyi, Nicotiana glaucum, Nicotiana silvestris, Nicotiana benthamiana, Nicotiana quadrivalvis and Nicotiana rusticana, as well as several tomato cultivars, including Rheinländer, Tigerella, Harzfeuer, Hellfrucht, Goldene Königin and St. Pierre. Red pepper and eggplant proved unsuitable. At certain stages of disease, moderate amounts of chromosomal
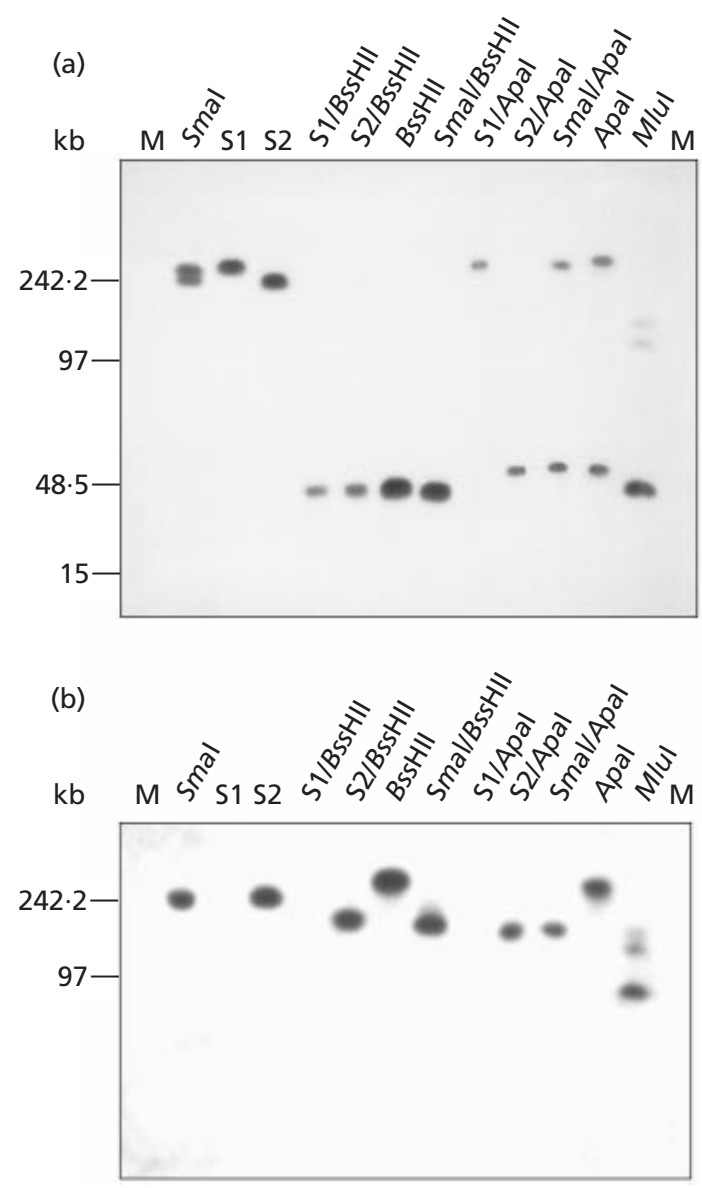

Fig. 2. Southern blot hybridization of DNA fragments in Fig. 1(a) probed with (a) randomly cloned DNA fragment IH184 and (b) a cloned DNA fragment containing a gene encoding the elongation factor Tu (tuf).

DNA were obtained from phloem preparations of Nicotiana glutinosa and the tomato cultivars Roma, Olivade, Hildares and Frühzauber. These genotypes were used for phytoplasma extraction.

\section{Restriction endonuclease digestion}

Strain GSFY1 chromosomal DNA was digested individually with 11 different restriction enzymes possessing GC-rich recognition sequences. Restriction enzymes NotI, BglI and Cfr42I failed to cleave the chromosomal DNA whereas digestions with SalI or HpaII yielded more than 10 fragments and were not used for mapping. Restriction enzymes SmaI, ApaI, BssHII, BamHI and Xhol produced two, three, five, six and ten fragments, respectively, and were chosen to construct the map (Table 1; see Figs 1, 3, 4, 6 and 7). PFGEpurified chromosomal DNA of strain GSFY1 was used to probe Southern blots of PFGE-separated SmaI, Bss HII, ApaI, BamHI and XhoI restriction fragments. The banding pattern revealed two, five, three, six and ten bands for SmaI, BssHII, ApaI, BamHI and XhoI, 

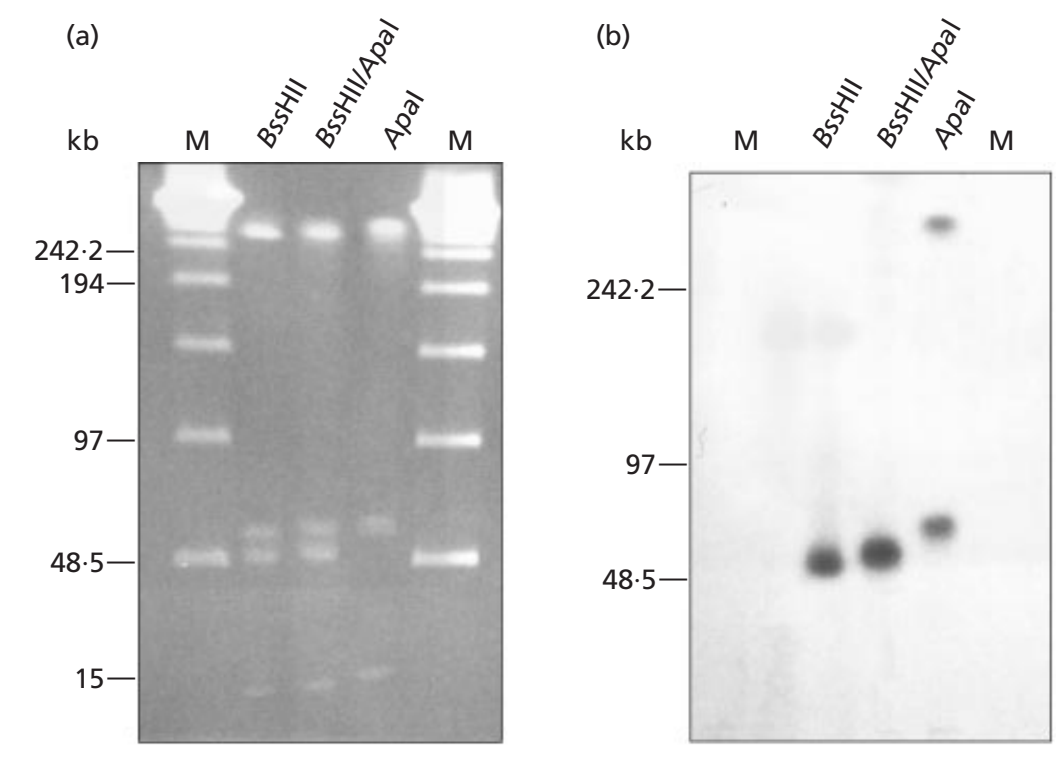

Fig. 3. $P F G E$ of chromosomal DNA of the ESFY phytoplasma. (a) Ethidium-bromidestained gel of single and double digests with various rare-cutting enzymes. PFGE parameters were $0.7-12.5 \mathrm{~s}, 6 \mathrm{~V} \mathrm{~cm}^{-1}, 18.8 \mathrm{~h}$. (b) Southern blot hybridization of DNA fragments obtained by single and double digestion with cloned DNA fragment probe IH184.

respectively, as seen in ethidium-bromide-stained gels. Reciprocal double digestions resulted in restriction fragments with sizes between 9 and $438 \mathrm{~kb}$ (Table 1 ; see Figs 1a, 3a, 4a, 6a and 7a). Analysis of the restriction data indicated that for each double digestion there must be, in addition to the clearly identified fragments, one or two fragments between 1 and $5 \mathrm{~kb}$ that were too small to be detected due to insufficient amounts of phytoplasma DNA in the gel (see Table 1). Different pulse parameters and running times were used so that the size of each restriction fragment could be determined under optimal electrophoretic conditions. Pulse times were varied between 0.7 and $120 \mathrm{~s}$, with different extents of ramping depending on the size range of molecules to be resolved. The mean size of restriction fragments, which was established from a minimum of three different gels, is shown in Table 1. From the sums of restriction fragments generated from all double digests, the size of the strain GSFY1 chromosome was calculated to be $635 \mathrm{~kb}$ (see Fig. 8). This value is slightly larger than the mean calculated from single digests $(633 \mathrm{~kb})$ as well as that estimated from the migration of entire chromosomes in the PFGE gels (630 kb) (Marcone et al., 1999b).

Digestion of chromosomal DNA of strain GSFY1 with MluI generated fragments whose combined size was larger than the expected $630-635 \mathrm{~kb}$ (Fig. 1a). On the basis of the difference in fluorescence intensity shown by the restriction fragments, two different profiles could be constructed. One of the profiles, designated MluI-A, consisted of seven fragments 194, 145, 122, 58, 48, 32 and $32 \mathrm{~kb}$ in size. The second profile, designated MluI$\mathrm{B}$, comprised the 194, 48, 32 and $32 \mathrm{~kb}$ fragments of profile MluI-A and contained two other fragments of 170 and $160 \mathrm{~kb}$. The phytoplasma nature of the latter two MluI fragments was confirmed by hybridization. In most preparations obtained from both tobacco and tomato, fragments of profile $M l u \mathrm{I}$-A showed a brighter fluorescence than the fragments of 170 and $160 \mathrm{~kb}$ of profile $M l u I-B$ (Fig. 1a). In only a few preparations, fragments of profile $M l u \mathrm{I}-\mathrm{B}$ showed a more intensive fluorescence than those of profile A, or fragments of both profiles showed the same fluorescence intensity (data not shown). Due to difficulties encountered in aligning $M l u \mathrm{I}$ fragments, the $M l u \mathrm{I}$ sites were not placed on the map.

\section{Map construction}

Data obtained on fragment sizes from single and reciprocal double digestions as well as from hybridization analyses were used to locate the restriction sites on the map shown in Fig. 8. Construction of the map started with double digestion of the strain GSFY1 chromosome with SmaI and BssHII, which showed that one of the two SmaI sites was located in the large BssHII fragment (Fig. 1a) whereas the second was very close to one of the BssHII sites. This BssHII site was chosen as the starting point of the map. From summation of resulting restriction fragments as well as from staining intensity, there was evidence that digestion of the strain GSFY1 chromosome with BssHII resulted in two fragments of $50 \mathrm{~kb}$ which could not be resolved by PFGE. In order to arrange these two fragments on the map, the 350 and $284 \mathrm{~kb}$ SmaI fragments, designated S1 and S2, respectively, were separated under appropriate PFGE conditions, excised from the gel and digested separately with BssHII. From each of the SmaI fragments, one $50 \mathrm{~kb}$ BssHII fragment was obtained (Fig. 1a). Southern blot hybridization with probe IH184 revealed that the two $50 \mathrm{~kb} \mathrm{BssHII}$ fragments were linked (Fig. 2a). The linking restriction site was chosen as the starting point of the map.

Double digestion of the chromosome with SmaI/ApaI and BssHII/ApaI and digestion of SmaI fragments with $A p a \mathrm{I}, A p a \mathrm{I}$ fragments with $S m a \mathrm{I}$ and BssHII fragments with ApaI (Figs 1a, 3a and data not shown) allowed 

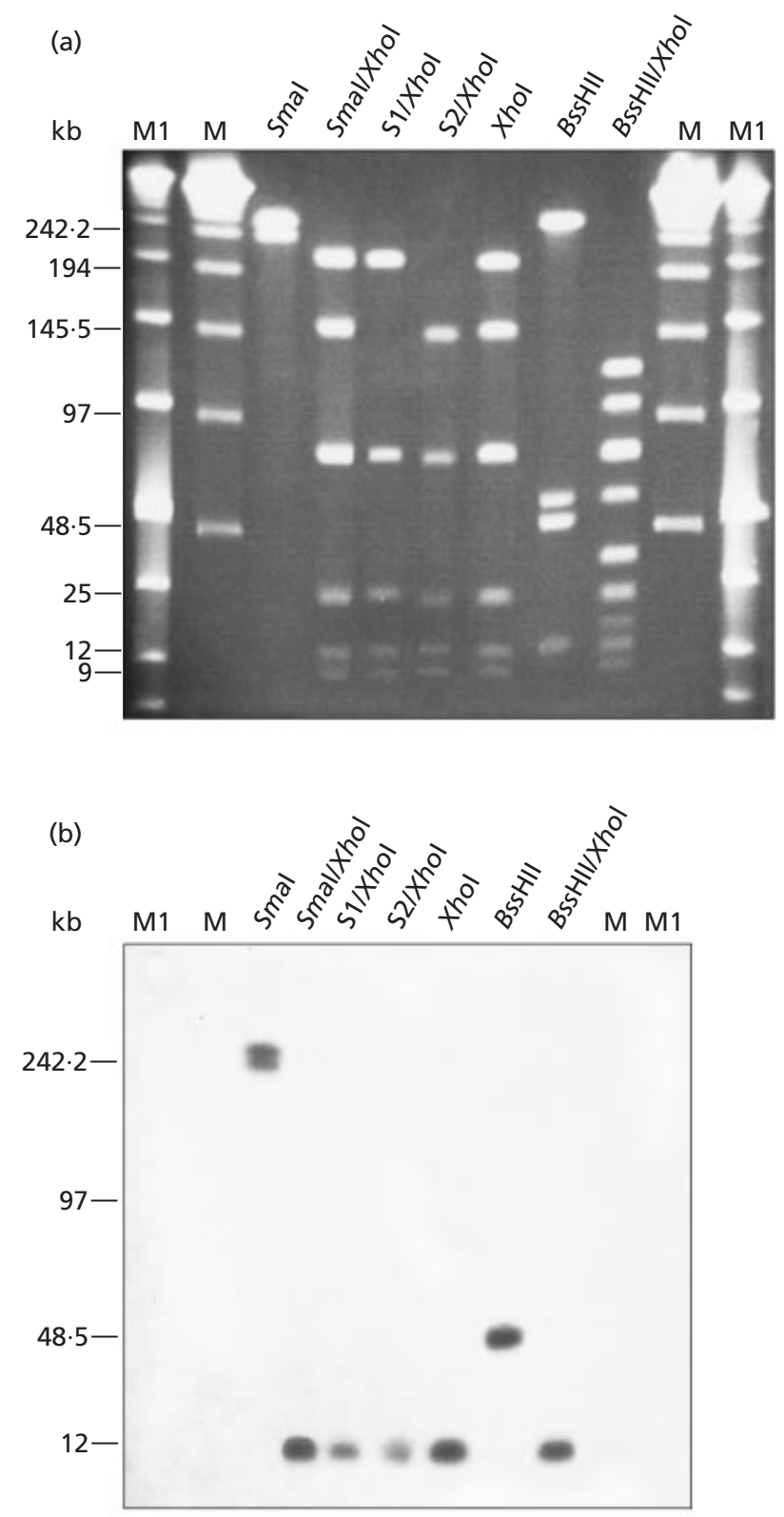

Fig. 4. PFGE of chromosomal DNA of the ESFY phytoplasma. (a) Ethidium-bromide-stained gel of single and double digests with various rare-cutting enzymes. S1, S2 and $M$, see Fig. 1 for abbreviations; M1, low range PFGE marker. PFGE parameters were $0 \cdot 7-12.5 \mathrm{~s}, 6 \mathrm{~V} \mathrm{~cm}-1,18 \cdot 8 \mathrm{~h}$. (b) Southern blot hybridization of DNA fragments obtained by single and double digestion with cloned DNA fragment probe IH184.

positioning of ApaI sites on the map. However, the ApaI site at position 632 proved to be very close to both $S m a \mathrm{I}$ and BssHII sites while the ApaI site at position 62 was close to one of the BssHII sites. Southern blot hybridization with probe $\mathrm{IH} 184$ revealed that the ApaI site at position 632 was located near the BssHII restriction site at the start point of the map (Figs $2 \mathrm{a}$ and 3b). Double digestions SmaI/BamHI, BssHII/BamHI and ApaI/BamHI were used to locate the sites for

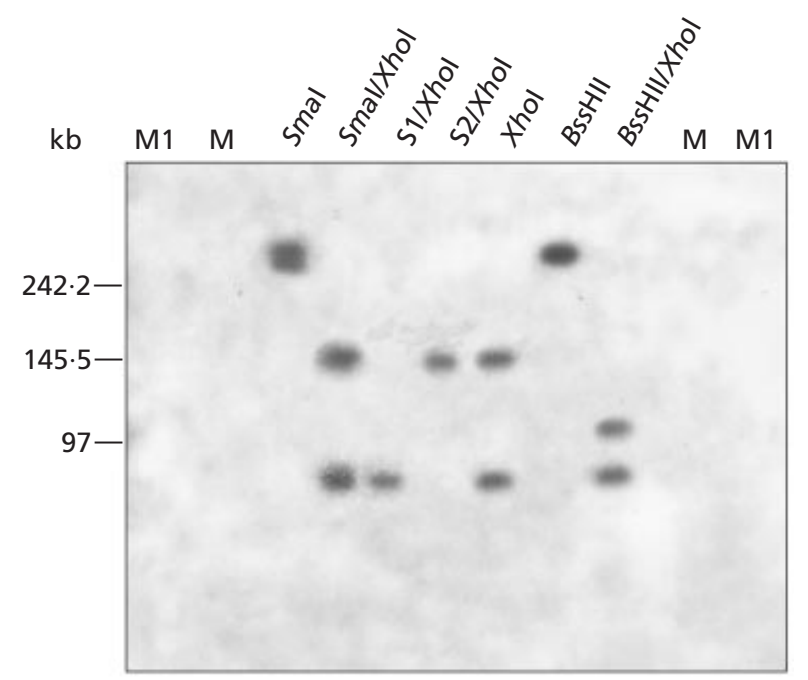

Fig. 5. Corresponding Southern blot hybridization of DNA fragments in Fig. 4(a) probed with a PCR-amplified $1800 \mathrm{bp}$ rDNA fragment of the ESFY phytoplasma containing the entire $16 \mathrm{~S}$ rRNA gene and 16S/23S rDNA spacer region.

BamHI relative to $S m a \mathrm{I}, B s s \mathrm{HII}$ and $A p a \mathrm{I}$ sites (see Figs $6 a$ and $7 a)$.

As there was evidence that XhoI digestion resulted in four doublets $80,25,12$ and $9 \mathrm{~kb}$ in size, their presence was verified by separate digestion of the two SmaI fragments with XhoI (Fig. 4a). Each of the resulting restriction patterns contained fragments of these four sizes. Southern blot hybridization with probe IH184 revealed that the $12 \mathrm{~kb}$ XhoI fragments were linked and were located near the BssHII site at position 0 (Figs $4 \mathrm{~b}$ and 8). This region also contained ApaI, SmaI and BamHI restriction sites (Figs 2a, 3b, 4b, 6d and 7d). Southern blot hybridization with the other gene probes allowed positioning of the other $X h o I$ sites within the S1 and S2 fragments and confirmed the position of other sites on the map. However, it was impossible to unambiguously allocate the restriction sites XhoI, SmaI, $B a m \mathrm{HI}$ and ApaI clustering with the BssHII site at position 0 because these sites were too close together and the fragments too small to be observed in pulsedfield gels. A similar situation was observed for the XhoI sites adjacent to the $S m a$ I site at position 283 .

The alignment of the restriction fragments revealed that the chromosome of strain GSFY1 was circular, like that of all other mycoplasmas previously examined. Several genetic loci were mapped by Southern hybridization of restriction fragments with various probes (Figs 1, 2, 3, 4, $5,6,7$ and data not shown). It could be shown that the two rRNA operons that seem to be present in all phytoplasmas were not linked (Fig. 5). The locus of the gene encoding the elongation factor $\mathrm{Tu}(t u f)$ was located on the same fragment as one of the rRNA operons while the randomly cloned fragment AT67 was located on the same fragment as the other rRNA operon (Figs 1b, 2b, 5, 

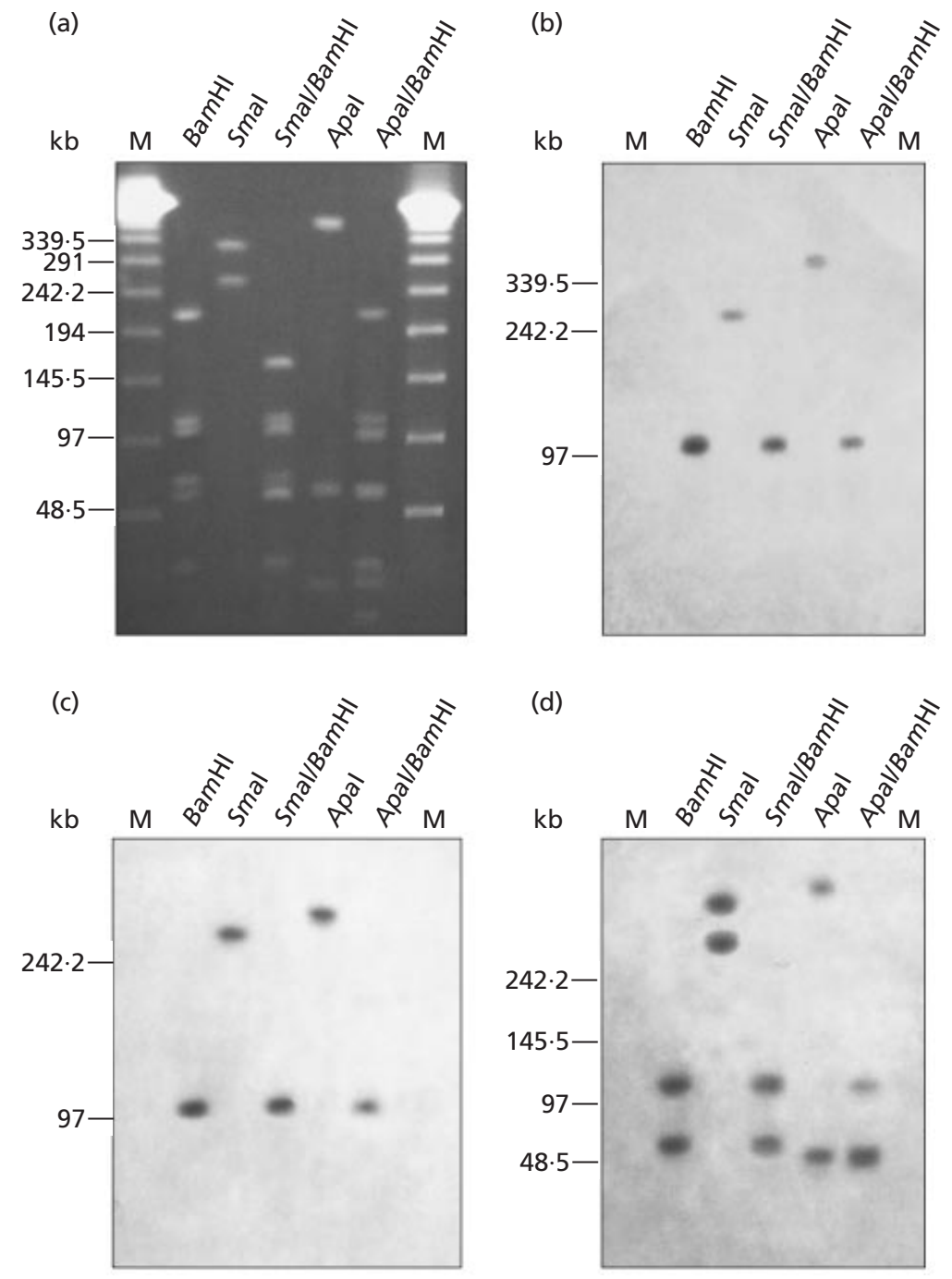

Fig. 6. PFGE and Southern blot hybridization of chromosomal DNA of the ESFY phytoplasma. (a) Ethidium-bromidestained gel of single and double digests with various rare-cutting enzymes. PFGE parameters were $1-21 \mathrm{~s}, 6 \mathrm{~V} \mathrm{~cm}^{-1}, 18.8 \mathrm{~h}$. (b-d) Corresponding Southern blot hybridization of DNA fragments obtained by single and double digestion probed with (b) a cloned DNA fragment containing a gene encoding the elongation factor Tu (tuf), (c) a cloned DNA fragment containing a gene encoding an immunodominant membrane protein and (d) randomly cloned DNA fragment IH184.
$6 \mathrm{~b}, 7 \mathrm{~b}, 8$ and data not shown). However, the position of both tuf and fragment AT67 relative to the positions of rRNA operons was not determined. The locus of the gene encoding an immunodominant protein as well as that of a putative nitroreductase gene were identified on the $65 \mathrm{~kb}$ BssHII and $56 \mathrm{~kb} B a m \mathrm{HI}-X h o I$ fragments, respectively (Figs $6 \mathrm{c}, 7 \mathrm{c}$ and 8 ). The randomly cloned fragment IH184 was identified within the $12 \mathrm{~kb}$ XhoI fragment containing the BssHII restriction site at position 0 (Figs 4 b and 8 ).

\section{DISCUSSION}

Sufficient chromosomal DNA of strain GSFY1 of the ESFY phytoplasma was obtained from a broad range of host plants including periwinkle and several solanaceous plants. Phloem preparations of N. glutinosa and the tomato cultivars Roma, Olivade, Hildares and Frühzauber were useful for genetic analysis only at certain stages of disease. N. glutinosa plants proved better than tomato for phloem preparations. The importance of suitable host plants was also emphasized by Firrao et al. (1996) and Lauer \& Seemüller (2000), who succeeded in mapping the WX and the AT phytoplasma chromosomes, respectively, using material extracted from infected celery and tobacco but not infected periwinkle plants. In contrast, infected periwinkle plants were used to map the chromosome of the SPLL phytoplasma (Padovan et al., 2000).

A total of 26 sites of five different restriction endonucleases were placed on the map of the GSFY1 chromosome of the ESFY phytoplasma. The mapped restriction sites were not uniformly distributed on the genome but clustered in certain areas. In particular, half of the restriction sites are located in the $100 \mathrm{~kb}$ region between positions 615 and 80, flanking the start point. A similar pronounced clustering of restriction sites is known for the chromosome of the phylogenetically closely related AP phytoplasma (Lauer \& Seemüller, 2000) and for several other mollicute genomes (Pyle \& Finch, 1988; Cocks et al., 1989; Colman et al., 1990; Ye et al., 1992). In contrast, the restriction sites mapped on the WX and SPLL phytoplasma chromosomes are evenly distributed (Firrao et al., 1996; Padovan et al., 2000). 

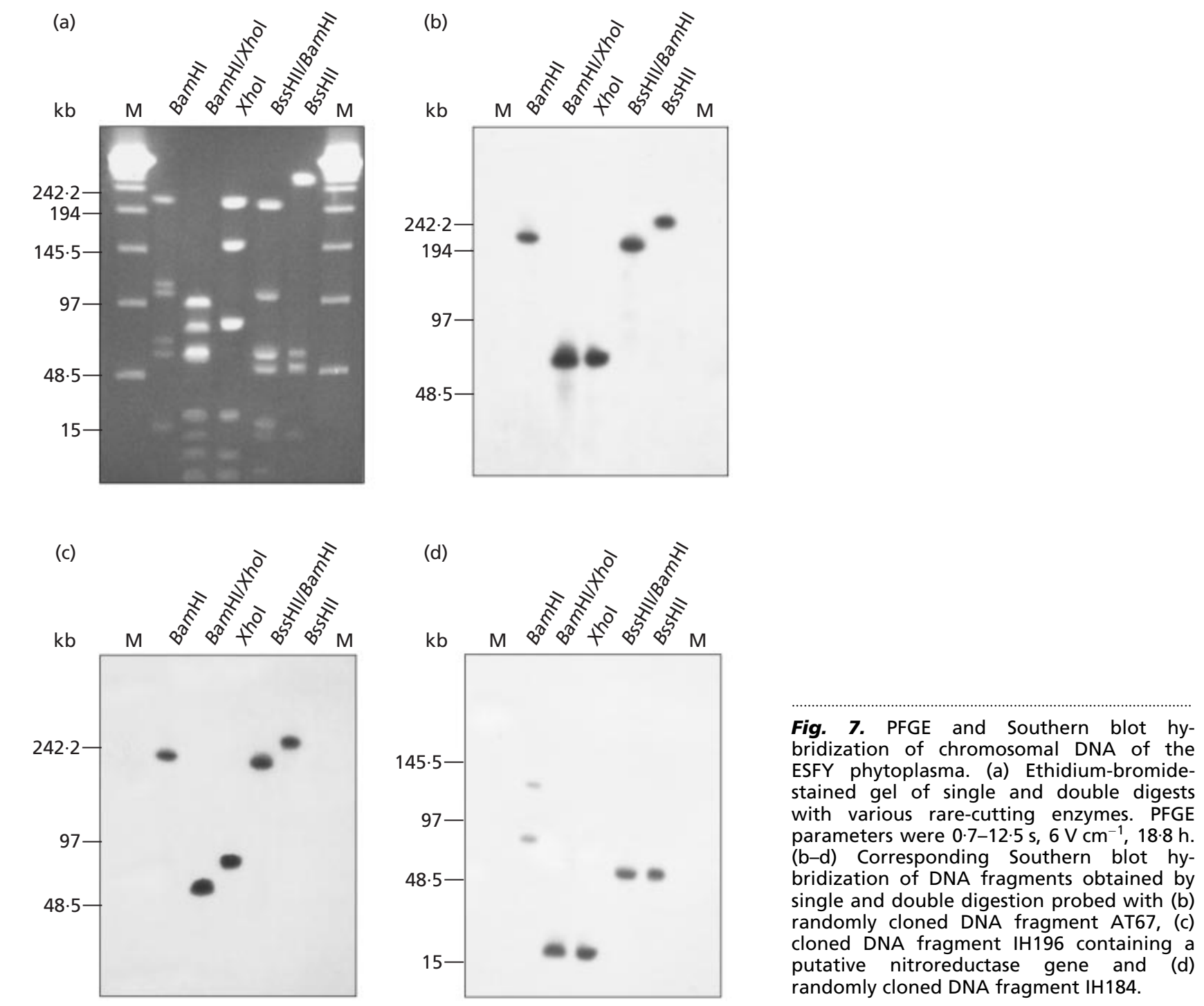

Clustering in the mapped restriction sites may indicate differences in the overall base composition of the regions involved. It is possible that the $100 \mathrm{~kb}$ region flanking the arbitrary starting point is richer in $\mathrm{G}+\mathrm{C}$ than other parts of the genome.

Most of the restriction enzymes we used were the same as those employed in the AP phytoplasma chromosome mapping. Comparisons of the maps showed that numbers and relative positions of restriction sites are conserved in only some cases. The three ApaI sites and the two $S m a$ I sites are in the same or similar positions as those reported for the AP phytoplasma chromosome. In contrast, strain GSFY1 has more BssHII sites than strain AT (five versus two) of which only one is at the same position (Lauer \& Seemüller, 2000). Also, there are only six BamHI sites in the GSFY1 chromosome while there are about 12 in the AT phytoplasma chromosome (E. Seemüller, unpublished). Different restriction patterns of closely related organisms are known for the SPLL and tomato big bud phytoplasmas (Padovan et al., 2000).
The same applies for five Mycoplasma hominis strains (Ladefoged \& Christiansen, 1992). Although only some of the restriction sites are conserved in strains GSFY1 and AT, the order of identified genes in the GSFY1 chromosome is similar to that of the AT phytoplasma chromosome. In both cases, the two rRNA operons are unlinked. Such a chromosomal arrangement is also known from the WX and SPLL phytoplasmas and some culturable mollicutes (Pyle \& Finch, 1988; Cocks et al., 1989; Pyle et al., 1990; Firrao et al., 1996; Padovan et al., 2000). As there is an indication that the gene order is conserved in several mollicutes (Pyle et al., 1990; Ladefoged \& Christiansen, 1992; Peterson et al., 1995; Himmelreich et al., 1997), this marker could be more appropriate than restriction sites in studying genomic diversity of mollicutes.

The presence of different $M l u \mathrm{I}$ restriction patterns, the fragments of which proved to be of phytoplasma nature, could be explained by the fact that strain GSFY1 consists of a phytoplasma population showing a sequence 


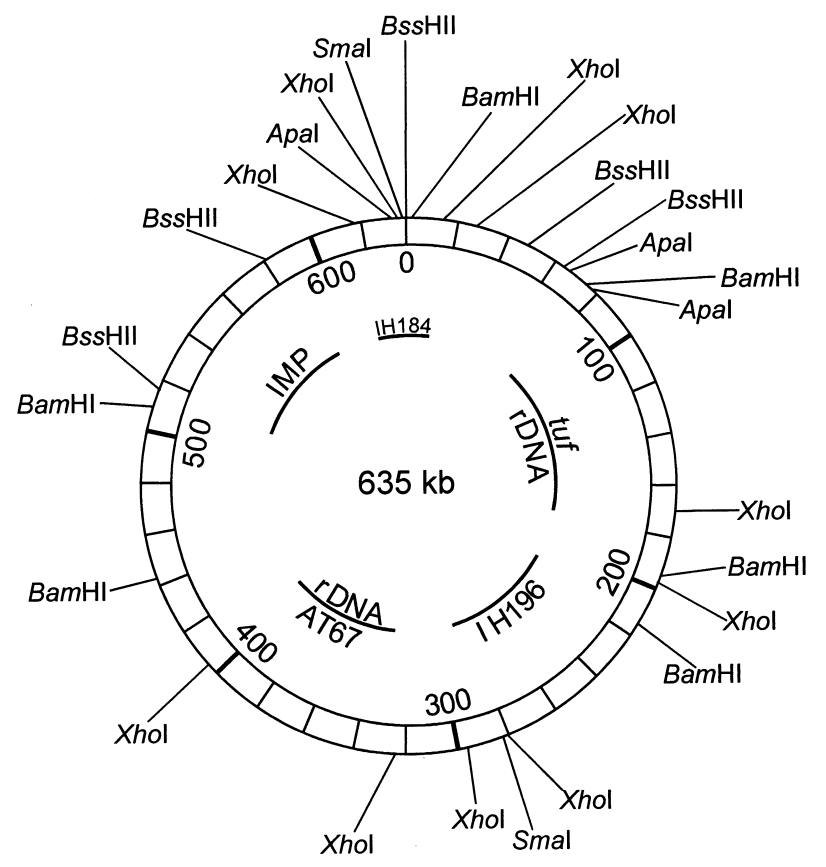

Fig. 8. Physical map of the chromosome of the ESFY phytoplasma. Restriction sites for Smal, BssHII, Apal, BamHI and $X$ hol are indicated. Loci of the two rRNA operons, the operon containing the tuf gene, an immunodominant membrane protein gene, a putative nitroreductase (IH196) gene and randomly cloned DNA fragments $\mathrm{IH} 184$ and AT67 were also mapped.

heterogeneity with respect to $M l u \mathrm{I}$ restriction sites. Similar observations have recently been reported for the SPLL and tomato big bud phytoplasma chromosomes (Padovan et al., 2000).

The physical map of the ESFY phytoplasma chromosome will further enhance genomic studies on this phytopathologically important phytoplasma, and will aid genome comparisons within the 'Candidatus Phytoplasma' genus.

\section{ACKNOWLEDGEMENTS}

We thank Luigi Carraro for providing strain ESFY1 of the ESFY phytoplasma and Felix Hergenhahn for performing the transmission work. The work was supported by a grant from the Commission of the European Communities to the first author (Research Training Grant FAIR-BM-974428).

\section{REFERENCES}

Berg, M. \& Seemüller, E. (1999). Chromosomal organization and nucleotide sequence of the genes coding for the elongation factors $\mathrm{G}$ and $\mathrm{Tu}$ of the apple proliferation phytoplasma. Gene 226, 103-109.

Berg, M., Davies, D. L., Clark, M. F., Vetten, H. J., Maier, G., Marcone, C. \& Seemüller, E. (1999). Isolation of a gene encoding an immunodominant membrane protein of apple proliferation phytoplasma, and expression and characterization of the gene product. Microbiology 145, 1937-1943.
Bonnet, F., Saillard, C., Kollar, A., Seemüller, E. \& Bové, J. M. (1990). Detection and differentiation of the mycoplasmalike organism associated with apple proliferation disease using cloned DNA probes. Mol Plant-Microbe Interact 3, 438-443.

Cocks, B. G., Pyle, L. E. \& Finch, L. R. (1989). A physical map of the genome of Ureaplasma urealiticum $960^{\mathrm{T}}$ with ribosomal RNA loci. Nucleic Acids Res 17, 6713-6719.

Colman, S. D., Hu, P.-C. \& Bott, K. F. (1990). A physical map of the Mycoplasma genitalium genome. Mol Microbiol 4, 683-687.

Firrao, G., Smart, C. D. \& Kirkpatrick, B. C. (1996). Physical map of the western X disease phytoplasma chromosome. J Bacteriol 178, 3985-3988.

Himmelreich, R., Plagens, H., Hilbert, H., Reiner, B. \& Herrmann, R. (1997). Comparative analysis of the genomes of the bacteria Mycoplasma pneumoniae and Mycoplasma genitalium. Nucleic Acids Res 25, 701-712.

Hoheisel, J. D., Lennon, G. G., Zehetner, G. \& Lehrach, H. (1991). Use of high coverage reference libraries of Drosophila melanogaster for relational data analysis; a step towards mapping and sequencing of the genome. J Mol Biol 220, 903-914.

Jarausch, W., Saillard, C., Dosba, F. \& Bové, J. M. (1994). Differentiation of mycoplasmalike organisms (MLOs) in European fruit trees by PCR using specific primers derived from sequence of a chromosomal fragment of the apple proliferation MLO. Appl Environ Microbiol 60, 2916-2923.

Ladefoged, S. A. \& Christiansen, G. (1992). Physical and genetic mapping of the genomes of five Mycoplasma hominis strains by pulsed-field gel electrophoresis. J Bacteriol 174, 2199-2207.

Lauer, U. \& Seemüller, E. (2000). Physical map of the chromosome of the apple proliferation phytoplasma. J Bacteriol 182, 1415-1418.

Loi, N., Carraro, L., Musetti, R., Pertot, I. \& Osler, R. (1995). Dodder transmission of two different MLOs from plum trees affected by 'leptonecrosis'. Acta Hortic 386, 465-470.

Lorenz, K.-H., Dosba, F., Poggi-Pollini, C., Llacer, G. \& Seemüller, E. (1994). Phytoplasma diseases of Prunus species in Europe are caused by genetically similar organisms. Z Pflanzenkr Pflanzenschutz 101, 567-575.

Marcone, C., Ragozzino, A. \& Seemüller, E. (1996). European stone fruit yellows phytoplasma as the cause of peach vein enlargement and other yellows and decline diseases of stone fruits in southern Italy. J Phytopathol 144, 559-564.

Marcone, C., Hergenhahn, F., Ragozzino, A. \& Seemüller, E. (1999a). Dodder transmission of pear decline, European stone fruit yellows, rubus stunt, picris echioides yellows and cotton phyllody phytoplasmas to periwinkle. J Phytopathol 147, 187-192.

Marcone, C., Neimark, H., Ragozzino, A., Lauer, U. \& Seemüller, E. (1999b). Chromosome sizes of phytoplasmas composing major phylogenetic groups and subgroups. Phytopathology 89, 805-810. Neimark, H. \& Kirkpatrick, B. C. (1993). Isolation and characterization of full-length chromosomes from non-culturable plantpathogenic mycoplasma-like organisms. Mol Microbiol 7, 21-28.

Padovan, A. C., Firrao, G., Schneider, B. \& Gibb, K. S. (2000). Chromosome mapping of the sweet potato little leaf phytoplasma reveals genome heterogeneity within the phytoplasmas. Microbiology 146, 893-902.

Peterson, S. N., Lucier, T., Heitzman, K., Smith, E. A., Bott, K. F., Hu, P.-C. \& Hutchison, C. A., III (1995). Genetic map of the Mycoplasma genitalium chromosome. J Bacteriol 177, 3199-3204.

Pyle, L. E. \& Finch, L. R. (1988). A physical map of the genome of 
Mycoplasma mycoides subsp. mycoides $\mathrm{Y}$ with some functional loci. Nucleic Acids Res 16, 2263-2268.

Pyle, L. E., Taylor, T. \& Finch, L. R. (1990). Genomic map of some strains within the Mycoplasma mycoides cluster. J Bacteriol 172, 7265-7268.

Schneider, B. \& Seemüller, E. (1994). Studies on the taxonomic relationships of mycoplasmalike organisms by Southern blot analysis. J Phytopathol 141, 173-185.

Schneider, B., Seemüller, E., Smart, C. D. \& Kirkpatrick, B. C. (1995). Phylogenetic classification of plant pathogenic mycoplasma-like organisms or phytoplasmas. In Molecular and
Diagnostic Procedures in Mycoplasmology, vol. I, pp. 369-380. Edited by S. Razin \& J. G. Tully. San Diego: Academic Press.

Seemüller, E., Marcone, C., Lauer, U., Ragozzino, A. \& Göschl, M. (1998). Current status of molecular classification of the phytoplasmas. J Plant Pathol 80, 3-26.

Ye, F., Laigret, F., Whitley, J. C., Citti, C., Finch, L. R., Carle, P., Renaudin, J. \& Bové, J. M. (1992). A physical and genetic map of the Spiroplasma citri genome. Nucleic Acids Res 20, 1559-1565.

Received 29 September 2000; revised 2 February 2001; accepted 12 February 2001. 